УДК 343.352

DOI https://doi.org/10.32837/pyuv.v0i1(30).542

\author{
I. Б. Юрчишин \\ orcid.org/0000-0001-6038-725X \\ детектив \\ Національного антикорупційного бюро України, \\ аспірант спеиіальної кафедри № 22 \\ Навчально-наукового інституту контррозвідувальної діяльності \\ Національної академї̈ Служби безпеки України
}

\title{
ГЕНЕЗИС КРИМІНАЛЬНОЇ ВІДПОВІДАЛЬНОСТІ ЗА НЕЗАКОННЕ ЗБАГАЧЕННЯ В УКРАЇНІ
}

Корупція нині становить проблему, розв'язання якої для багатьох країн є надзвичайно актуальним питанням. Це повною мірою стосується і України, високий рівень корумпованості в якій визнається керівництвом держави, міжнародними інституціями та незалежними антикорупційними організаціями.

Корупція, безперечно, є загрозою національній безпеці України, уповільнює економічний розвиток держави, що є відчутним бар'єром для надходження іноземних інвестицій, а також нівелює довіру населення до державних органів та органів місцевого самоврядування, а також судової системи. Крім того, масштаби корупційних проявів негативно позначаються на міжнародному іміджі України.

Розбудова України як демократичної, правової держави, в якій визнається і діє принцип верховенства права, вимагає запровадження ефективної, передбачуваної та такої, що відповідала б правомірним очікуванням громадян України, антикорупційної політики для захисту конституційних цінностей, прав і свобод людини і громадянина [1, с. 4].

У рішенні Конституційного Суду України від 26.02.2019 р. № 1-p/2019 у справі за конституційним поданням 59 народних депутатів України щодо відповідності Конституції України (конституційності) ст. 368-2 Кримінального кодексу України зазначається, що корупція є однією 3 основних загроз національній безпеці України, а протидія корупції має здійснюватися виключно правовими засобами з дотриманням конституційних принципів та приписів законодавства, ухваленого відповідно до Конституції України [2, с. 5].

Антикорупційна політика держави передбачає низку заходів та засобів (у тому числі правового, економічного, організаційного змісту), які окремо та в сукупності мають бути ефективними та адекватними в боротьбі чи іншій протидії корупції [2, с. 3].

Конституційний Суд України у своєму Рішенні наголошує, що протидія корупції в Україні є завданням виняткового суспільного та державного значення, а криміналізація незаконного збага- чення - важливим юридичним засобом реалізації державної політики в цій сфері [2, с. 17].

У відповідь на поширення корупції держави вдаються до різних, переважно інноваційних, підходів у сфері кримінально-правової політики з метою забезпечення невідворотності покарання за корупцію. Одним із таких заходів є криміналізація незаконного збагачення, в основі філософії якого лежить неприйняття практики збільшення статків посадовця, що не може бути розумно пояснене і відбулося під час перебування його чи їі на посаді [3, с. 4-5].

Кримінально-правову характеристику незаконного збагачення досліджували такі українські науковці: Д.О. Гарбазей, О.I. Гузоватий, О.П. Денега, 0.О. Дудоров, К.П. Задоя, В.М. Киричко, О.О. Книженко, М.В. Кочеров, В.Н. Кубальський, М.I. Мельник, В.А. Мисливий, Д.Г. Михайленко, В.О. Навроцький, В.Я. Тацій, Т.М. Тертиченко, P.В. Трофименко, В.I. Тютюгін, М.I. Хавронюк, О.Ю. Шостко.

Значну увагу дослідженню проблематики незаконного збагачення приділяли зарубіжні науковці та експерти: І. Данєлєне, Г. Дордж, Д. Жалімас, Н. Кофеле-Кале, Н. Гачері Камунде, К. Мюллер, Н. Цоцорія.

Однак після вжиття законодавцем заходів, спрямованих на відновлення кримінальної відповідальності за вказаний злочин та доповнення КК України ст. 368-5, сучасний стан кримінальної відповідальності за незаконне збагачення залишається малодослідженим.

Кримінальна відповідальність за незаконне збагачення - один із правових інструментів боротьби з корупцією в загальному механізмі протидії цьому негативному явищу, який безперечно характеризується потужним превентивним та каральним антикорупційним потенціалом і органічно пов' язаний та кореспондується з обов' язком держави боротися 3 корупцією чи іншим чином протидіяти їй [4, с. 2].

Кримінальна відповідальність за незаконне збагачення є одним із фундаментів поточної антикорупційної політики та інституційної реформи у сфері боротьби з корупцією в Україні [3, с. 11]. 
Варто погодитися з твердженням судді КСУ 0.0. Первомайського, який зазначає, що кримінальна відповідальність у сфері корупційних правопорушень $€$ ultima ratio в протидії корупції, тобто останнім правовим засобом державного примyсу [4, с. 3].

Поряд із цим антикорупційна політика держави не має обмежуватися виключно запровадженням заходів державного примусу, до яких можна зарахувати криміналізацію незаконного збагачення, а перш за все бути спрямована на: формування суспільної свідомості щодо неприйнятності корупції або, іншими словами, утвердження нульової толерантності до корупції; реалізацію заходів превенції у сфері запобігання корупції, антикорупційне реформування інститутів держави та суспільства.

Таким чином, кримінальну відповідальність за незаконне збагачення можна визначити як один із правових інструментів та суворий засіб державного примусу в загальному механізмі протидії корупції, який характеризується потужним превентивним та каральним антикорупційним потенціалом і органічно пов'язаний та кореспондується з обов'язком держави боротися чи іншим чином протидіяти корупції, а також є одним із фундаментів поточної антикорупційної політики та інституційної реформи у сфері боротьби з корупцією в Україні.

Україна пройшла унікальний шлях встановлення та трансформації кримінальної відповідальності за незаконне збагачення.

Умовно історію становлення та розвитку кримінальної відповідальності за незаконне збагачення в Україні можна поділити на п'ять етапів.

До першого emany варто зарахувати ратифікацію Україною 18.10.2006 р. Конвенції Організації Об’єднаних Націй проти корупції від 31.10.2003 p. (далі - Конвенція).

У п. 1 ст. 5 Конвенції зазначено: «Кожна Держава-учасниця, згідно з основоположними принципами своєї правової системи, розробляє й здійснює або проводить ефективну скоординовану політику протидії корупції, яка сприяє участі суспільства і яка відображає принципи правопорядку, належного управління державними справами й державним майном, чесності й непідкупності, прозорості й відповідальності» [5].

Ст. 20 Конвенції встановлює: «За умови дотримання своєї конституції та основоположних принципів своєї правової системи кожна Держава-учасниця розглядає можливість вжиття таких законодавчих та інших заходів, які можуть бути необхідними для визнання злочином умисне незаконне збагачення, тобто значне збільшення активів державної посадової особи, яке перевищує iї законні доходи і які вона не може раціонально обгрунтувати» [5].
Відповідно до припису ч. 1 ст. 9 Конституції України, Конвенція стала частиною українського законодавства [6]. 3 огляду на те, що укладення Україною міжнародного договору, який суперечить їі Конституції, є можливим лише після внесення відповідних змін до Конституції (ч. 2 ст. 9 Конституції України), а в процесі ратифікації цієї Конвенції ніхто не порушив питання про потребу вносити у зв'язку з цим зміни до Конституції, є юридичні підстави вважати приписи ст. 20 Конвенції (як норми українського законодавства) такими, що відповідають Конституції України. Отже, імплементацію ст. 20 Конвенції в українське кримінальне законодавство було здійснено 3 «дотриманням національної конституції, «основоположних принципів національної юридичної системи» та в рамках «принципів і норм Конституції України» [7, с. 11].

Таким чином, Україна як Держава-учасниця Конвенції $\mathrm{OOH}$ розпочала розглядати можливість криміналізації незаконного збагачення «за умови дотримання своєї Конституції та основоположних принципів своєї правової системи» .

До другого emany можна зарахувати першу спробу гармонійної імплементації до вітчизняної правової системи такого важливого юридичного засобу протидії корупції, як криміналізація незаконного збагачення, яка відбулася у 2011 р. КК України було доповнено ст. 368-2 згідно із змінами, внесеними Законом України (далі - Закон) «Про внесення змін до деяких законодавчих актів України щодо відповідальності за корупційні правопорушення» № 3207-VI від 07.04.2011 p.

Зокрема, ч. 1 ст. 368-2 КК України незаконне збагачення визначалося як одержання службовою особою неправомірної вигоди у значному розмірі або передача нею такої вигоди близьким родичам за відсутності ознак хабарництва (незаконне збагачення).

Диспозиції ч. 2 та 3 ст. 368-2 КК Україна визначали кримінальну відповідальність за незаконне збагачення, якщо його предметом була неправомірна вигода у великих та особливо великих pозмірах, а у примітці до ст. 368-2 КК України визначалося, що вважається неправомірною вигода у значному, великому та особливо великому poзмipi [8].

У цьому випадку, як слушно зазначає В.О. Навроцький, "кримінальний закон сам зобов'язує проводити розмежування між злочинами, передбачаючи відповідальність за певними статтями КК України лише при відсутності ознак інших посягань» [15, с. 477].

На думку 0.0. Дудорова, без зазначення у КК України такої юридичної конструкції, як «за відсутності ознак хабарництва», було зрозуміло, що встановлення причинного зв'язку між одержанням неправомірної вигоди і дією (бездіяльністю) 
службової особи з використанням свого службового становища (тобто ознаки об'єктивної сторони складу злочину "одержання хабара») мало виключати застосування статті КК України про відповідальність за незаконне збагачення, а інтереси боротьби з корупцією навряд чи вимагали встановлення кримінальної відповідальності за одержання службовою особою неправомірної вигоди, зокрема «за встановлення дружніх стосунків», "про всяк випадок», «за встановленою хибною практикою», якщо відповідне ставлення з боку службової особи не виражається в діях чи бездіяльності з використанням свого службового становища [16, с. 130].

До другого етапу можна також зарахувати зміни до диспозиції та санкції ст. 362-2 КК України, а також примітки до неї, які вносилися двічі, згідно із Законами № 221-VII від 18.04.2013 р., № 222-VII від 18.04.2013 р.

Зокрема, згідно із Законом № 221-VII від 18.04.2013 р. примітку до ст. 368-2 викладено у такій редакції: «Під неправомірною вигодою слід розуміти грошові кошти або інше майно, переваги, пільги, послуги, нематеріальні активи, які пропонують, обіцяють, надають або одержують без законних на те підстав», а в абзаці першому частини першої статті 368-2 термін «хабарництво» був замінений на «прийняття пропозиції, обіцянки або одержання неправомірної вигоди службовою особою» [9].

Зміни до ст. 368-2, внесені згідно із Законом № 222-VII від 18.04.2013 р., передбачали доповнення санкції ст. 368-2 КК України, запроваджували такий вид покарання, як «конфіскація майна», та такий захід кримінально-правового характеру, як «спеціальна конфіскація» [9].

На думку 0.0. Дудорова, у період чинності наведеної вище редакції кримінально-правової заборони щодо незаконного збагачення в судовій практиці зазвичай визнавалось, що ст. 368-2 і ст. 368 КК України співвідносяться між собою як загальна і спеціальна норми, а передбачені ними діяння є проявами кримінально караної корупції. 0.0. Дудоров зазначає, що насправді співвідношення вказаних статей КК України не підпадало під поняття конкуренції кримінально-правових норм, а давало змогу говорити про передбачені цими статтями КК України суміжні склади злочину [16, с. 130].

Tpemiǔ eman. У 2014 та 2015 рр. текст ст. 3682 був викладений у нових редакціях згідно із Законами № 1698-VII від 14.10.2014 р. та № 198-VIII від 12.02.2015 p.

Проаналізувавши вимоги законодавства, можна дійти висновку, що вказана редакція ст. 3682 КК України з'явилася у зв'язку з прийняттям та набранням чинності Закону України «Про запобігання корупції» № 1700-VII від 14.10.2014 р., створенням нової системи антикорупційних органів, а також повноцінним запуском системи електронного декларування.

Згідно з ч. 1 ст. 368-2 КК України в редакції згідно із Законом № 1698-VII від 14.10.2014 р. незаконне збагачення визначалося як набуття особою, уповноваженою на виконання функцій держави або місцевого самоврядування, у власність майна, вартість якого значно перевищує доходи особи, отримані із законних джерел, або передача нею такого майна близьким родичам.

Диспозиції ч. 2 та 3 ст. 368-2 КК Україна встановлювали кримінальну відповідальність за незаконне збагачення як діяння, передбачені ч. 1 цієї статті, вчинені службовою особою, яка займає відповідальне становище, та вчинені службовою особою, яка займає особливо відповідальне становище [11].

Через нетривалий проміжок часу у зв'язку 3 прийняттям Закону України «Про внесення змін до деяких законодавчих актів України щодо забезпечення діяльності Національного антикорупційного бюро України та Національного агентства з питань запобігання корупції» № 198-VIII від 12.02.2015 р. текст ст. 368-2 КК України викладено в новій редакції [12].

Проаналізувавши вимоги законодавства, можна дійти висновку, що законодавець змінює деякі юридичні конструкції, зокрема термін «майно» на більш ширше поняття «активи», а кримінальна відповідальність за незаконне збагачення наступатиме, якщо законність підстав набуття активів не підтверджена доказами. Зміни стосувалися також того, що передача таких активів може здійснюватися будь-якій іншій особі, а не тільки близьким родичам, як це було передбачено в попередній редакції ст. 362-2 КК України.

У зв'язку з удосконаленням інституту спеціальної конфіскації з метою усунення корупційних ризиків у процесі їі застосування були внесені зміни до санкції ст. 368-2 згідно із Законом № 770-VIII від 10.11.2015 р., які скасували такий захід кримінально-правового характеру, як «спеціальна конфіскація» [13].

І.Д. Сліденко вказує на прагматичний аспект появи цієї норми, який пов'язаний із тим, що ст. 368-2 у новій редакції була прийнята у 2015 р. на хвилі створення нової системи антикорупційних органів. Поява цієї норми була необхідна для повноцінного запуску системи електронного декларування, що, своєю чергою, було однією з умов отримання Україною безвізового режиму з ЄС. Аналогічна вимога була висунута і для продовження співпраці України з кредиторами, зокрема і з Міжнародним валютним фондом [10, с. 6].

На думку І.Д. Сліденка, зазначена норма мала стати бар’єром на шляху корупції в публічній сфеpi, насамперед у політиці. Ї̈ї призначення полягало 
в тому, щоб під загрозою кримінального покарання публічні особи відмовлялися від підкупу в тих чи інших формах осіб, які бажають незаконним шляхом вплинути на прийняття політичних або адміністративних рішень на свою користь [10, с. 6].

Четвертій eman. Рішенням Конституційного Суду України від 26.02.2019 р. № 1-р/2019 ст. 368-2 КК України, якою було передбачено кримінальну відповідальність за незаконне збагачення, визнано такою, що не відповідає Конституції України.

Із Рішення вбачається, що Конституційний Суд України визнав неконституційною ст. 368-2 КК України, якою визначено склад такого злочину, як незаконне збагачення, оскільки ця стаття не відповідає вимозі юридичної визначеності як складової частини конституційного принципу верховенства права (ч. 1 ст. 8 Конституції України), не узгоджується 3 конституційним принципом презумпції невинуватості (ч.ч. 1, 2, 3 ст. 62 Конституції України) та з конституційним приписом щодо неприпустимості притягнення особи до відповідальності за відмову давати показання або пояснення щодо себе, членів сім'ї чи близьких родичів (ч. 1 ст. 63 Конституції України).

Варто зазначити, що вказане рішення КСУ викликало гучний резонанс не тільки в Україні. Так, голова правління Transparency International Д. Феррейра Рубіо звернула увагу на існування системних законодавчих проблем в Україні. На її погляд, якщо ці проблеми не будуть вирішені і справи про незаконне збагачення залишаться без розгляду, значна кількість антикорупційних досягнень у державі стануть марними, а безвізовий режим з Свропейським Союзом та фінансова допомога МВФ можуть бути заморожені, що, своєю чергою, загрожуватиме економічному розвитку країни [14].

На думку тодішнього надзвичайного та повноважного посла США в Україні М. Йованович, рішення КСУ щодо скасування статті про незаконне збагачення є серйозним відступом у боротьбі з корупцією в Україні. Воно послаблює антикорупційну архітектуру України, включаючи створюваний нині Вищий антикорупційний суд та Національне антикорупційне бюро України [15].

Незважаючи на реакцію соціуму в Україні та західних демократіях, яка полягає в різкій критиці, вказане рішення КСУ є обов'язковим, остаточним та таким, що не може бути оскаржено, а ст. 368-2 КК України була вилучена з КК України.

В окремій думці стосовно Рішення І.Д. Сліденко наголошує, що рішення декриміналізувало статтю про незаконне збагачення. При цьому було не лише визнано неконституційними формулювання складу злочину у редакції 2015 р., а й скасовано караність такого діяння, звільнено підозрюваних і обвинувачених у незаконному збагаченні осіб від кримінальної відповідальності. Якщо нор- ма про кримінальну відповідальність за незаконне збагачення буде повернута до КК України, вона не матиме зворотної сили. Таким чином, на думку І.Д. Сліденка, екстремальний підхід КСУ зруйнував практику роботи системи новостворених антикорупційних органів [10, с. 18].

У рішенні зазначається, що в процесі визначення злочином такого діяння, як незаконне збагачення, треба обов'язково враховувати конституційні положення, якими встановлено принципи юридичної відповідальності, права і свободи людини і громадянина, а також їх гарантії. За приписами ст.ст. 62, 63 Конституції України законодавчим формулюванням складу такого злочину, як незаконне збагачення, не можна: покладати на особу обов'язок підтверджувати доказами законність підстав набуття нею у власність активів, тобто доводити свою невинуватість; надавати стороні обвинувачення право вимагати від особи підтвердження доказами законності підстав набуття нею у власність активів; уможливлювати притягнення особи до кримінальної відповідальності лише на підставі відсутності підтвердження доказами законності підстав набуття нею у власність активів [2, с. 17].

С.В. Шевчук вважає, що до цього переліку також додати такі критеріі, що випливають 3 антикорупційного конституційного принципу: незаконне збагачення має охоплювати всі речові права, які можуть набувати особи, уповноважені на виконання функцій держави або місцевого самоврядування, внаслідок корупційної діяльності; злочин незаконного збагачення повинен мати характер продовжуваного злочину (цим усувається ризик у неконституційної ретроактивності і забезпечується дотримання принципу crime does not рау); формулювання має чітко визначати умисність цього злочину [3, с. 12].

Крім того, С.В. Шевчук зазначає, що законодавець має ретельно і виважено підійти до формулювання поняття «злочин незаконного збагачення» [3, с. 11$]$.

П’ятий eman. Враховуючи, що відсутність кримінальної відповідальності за незаконне збагачення нівелювала роль системи електронного декларування у попередженні та виявленні корупції, а в суб'єктів декларування були відсутні правові перешкоди для декларування незаконно набутого майна, з метою дотримання Україною взятих на себе міжнародних зобов'язань законодавець вжив заходів, спрямованих на відновлення кримінальної відповідальності за вказаний злочин. КК України був доповнений ст. 368-5 згідно із Законом «Про внесення змін до деяких законодавчих актів України щодо конфіскації незаконних активів осіб, уповноважених на виконання функцій держави або місцевого самоврядування, і покарання за набуття таких активів» № 263-IX від 31.10.2019 p. 
Завданням закону є відновлення кримінальної відповідальності за незаконне збагачення, а також запровадження інституту стягнення в дохід держави необгрунтованих активів осіб, уповноважених на виконання функцій держави або місцевого самоврядування.

Згідно з прийнятим законом, під незаконним збагаченням розуміється набуття особою, уповноваженою на виконання функцій держави або місцевого самоврядування, активів, вартість яких більше ніж на шість тисяч п'ятсот неоподатковуваних мінімумів доходів громадян перевищуе іï законні доходи.

Примітка 1 до ст. 368-5 містить відсилочні норми на положення Закону України «Про запобігання корупції», де визначаються поняття «особи, уповноваженої на виконання функцій держави або місцевого самоврядування».

Примітка 2 до ст. 368-5 визначає, що розуміється під "набуттям активів», у примітці 3 зазначено, що варто розуміти під "активами», примітка 4 визначає, що розуміється під «законними доходами особи».

У примітці 5 до ст. 368-5 КК України зазначається, що в процесі визначення різниці між вартістю набутих активів та законними доходами не враховуються активи, які є предметом провадження у справах про визнання активів необгрунтованими та їх стягнення в дохід держави, а також активи, стягнуті в дохід держави в рамках такого провадження [16].

Варто зазначити, що міжнародна спільнота та українські експерти у сфері антикорупційної політики одностайно вітали відновлення в Україні кримінальної відповідальності за незаконне збагачення.

Так, Світовий банк у заяві зазначив, що вітає закон, який заповнюе критичні прогалини в основних принципах протидії корупції в Україні, надавши НАБУ і САП потужний правовий інструмент у боротьбі з корупцією серед чиновників [17]. Схожу позицію висловило Посольство США в Україні, вказавши у своїй заяві, що підтримує підписання президентом В. Зеленським законопроєкту № 1031, який криміналізує незаконне збагачення та запроваджує механізм цивільної конфіскації [18].

Таким чином, із моменту запровадження кримінальної відповідальності за незаконне збагачення і донині кримінально-правова норма «незаконне збагачення» шість разів зазнавала змін, була декриміналізована Рішенням КСУ та знову визначено злочином таке діяння, як незаконне збагачення. Така ситуація пояснюється тим, що законодавець перебуває в пошуку найоптимальнішої моделі вказаної кримінально-правової норми, яка б, з одного боку, була ефективним правовим інструментом боротьби 3 корупцією, а з іншого враховувала конституційні положення, якими встановлено принципи юридичної відповідальності, права і свободи людини і громадянина, а також їх гарантії.

\section{Jimepamypa}

1. Рішення Конституційного Суду України від 06.06.2019 № 3-p/2019 у справі за конституційними поданнями Уповноваженого Верховної Ради України 3 прав людини та 65 народних депутатів України щодо відповідності Конституції України (конституційності) положень пункту 5 частини першої статті 3 , абзацу третього частини третьої статті 45 Закону України «Про запобігання корупції», пункту 2 розділу II «Прикінцеві положення» Закону України «Про внесення змін до деяких законів України щодо особливостей фінансового контролю окремих категорій посадових ociб». URL: http://www.ccu.gov.ua/sites/default/files/ docs/3_p_2019.pdf.

2. Рішення Конституційного Суду України від 26.02.2019 p. № 1-p/2019 у справі за конституційним поданням 59 народних депутатів України щодо відповідності Конституції України (конституційності) статті 368-2 Кримінального кодексу України. URL: http://www.ccu.gov.ua/sites/default/files/docs/ 1_p 2019.pdf.

$\overline{3}$. Шевчук С.В. Окрема думка судді Конституційного суду Шевчука С.В. у справі за конституційним поданням 59 народних депутатів України щодо відповідності Конституції України (конституційності) статті 368-2 Кримінального кодексу України. URL: http://www.ccu.gov.ua/sites/default/files/docs/1_p_ 2019 - 7 0.pdf.

4. Первомайський 0.0. Окрема думка судді Конституційного суду Первомайського О.O. у справі за конституційним поданням 59 народних депутатів України щодо відповідності Конституції України (конституційності) статті 368-2 Кримінального кодексу України. URL: http://www.ccu.gov.ua/sites/default/ files/docs/1_p_2019_4_0.pdf.

5. Конвенція Організації Об'єднаних Націй проти корупції від 31.10.2003 р., ратифікована Верховною Радою України 18.10.2006. URL: https://zakon.rada.gov.ua/laws/show/995 c16.

6. Конституція України від 28.06.19 96 p. URL: https://zakon.rada.gov.ua/laws/show/ $254 \%$ D0 \% BA $/ 96-\%$ D0 $\%$ B2 $\%$ D $1 \% 80$.

7. Головатий С.П. Окрема думка судді Конституційного суду Шевчука С.В. у справі за конституційним поданням 59 народних депутатів України щодо відповідності Конституції України (конституційності) статті 368-2 Кримінального кодексу України (оновлена й доповнена 11.03.2019 p.). URL: http://www.ccu.gov.ua/ sites/default/files/docs/1 p 2019 3.pdf.

8. Про внесення змін до деяких законодавчих актів України щодо відповідальності за корупційні правопорушення : Закон України № 3207-VI від 07.04.2011 p. URL: https://zakon.rada.gov.ua/laws/show/3207-17.

9. Про внесення змін до деяких законодавчих актів України щодо приведення національного законодавства у відповідність із стандартами Кримінальної конвенції про боротьбу з корупцією : Закон України № 221-VII від 18.04.2013 р. URL: https://zakon.rada.gov.ua/laws/ show/221-18\#n40.

10. Про внесення змін до Кримінального та Кримінального процесуального кодексів України стосовно виконання Плану дій щодо лібералізації Європейським Союзом візового режиму для України : Закон України № 222-VII від 18.04.2013 p. URL: https://zakon.rada. gov.ua/laws/show/222-18\#n31. 
10. Сліденко І.Д. Окрема думка судді Конституційного суду Первомайського 0.0. у справі за конституційним поданням 59 народних депутатів України щодо відповідності Конституції України (конституційності) статті 368-2 Кримінального кодексу України. URL: http://www.ccu.gov.ua/sites/default/files/ docs $/ 1$ p 20198 0.pdf.

11. Про Національне антикорупційне бюро України : Закон України № 1698-VII від 14.10.2014 p. URL: https://zakon.rada.gov.ua/laws/show/1698-18.

12. Про внесення змін до деяких законодавчих актів України щодо забезпечення діяльності Національного антикорупційного бюро України та Національного агентства 3 питань запобігання корупції : Закон України № 198-VIII від 12.02.2015 p. URL: https:// zakon.rada.gov.ua/laws/show/198-19.

13. Про внесення змін до Кримінального кодексу України щодо вдосконалення інституту спеціальної конфіскації з метою усунення корупційних ризиків при її застосуванні : Закон України № 770-VIII від 10.11.2015 p. URL: https://zakon.rada.gov.ua/laws/ show/770-19.

14. Незаконне збагачення: наслідки скасування закону. URL: http://khpg.org/index.php?id=1551789474.

15. Виступ посла США в Україні Марі Йованович 3 нагоди 5-ої річниці заснування Українського кризового медіа-центру (УКМЦ). URL: https://ua.usembassy. gov/uk/remarks-by-ambassador-yovanovitch-on-theoccasion-of-the-5th-anniversary-of-the-ukraine-crisismedia-centers-founding/.

16. Про внесення змін до деяких законодавчих актів України щодо конфіскації незаконних активів осіб, уповноважених на виконання функцій держави або місцевого самоврядування, і покарання за набуття таких активів : Закон України № 263-IX від 31.10.2019 p. URL: https://zakon.rada.gov.ua/laws/show/263-20/.

17. Світовий банк вітає відновлення в Україні кримінальної відповідальності за незаконне збагачення. URL: https://uatv.ua/svitovyj-bank-vitayepidpysannya-volodymyrom-zelenskym-zakonu-pronezakonne-zbagachennya/.

18. Посольство США привітало Зеленського 3 відновленням кримінальної відповідальності за незаконне збагачення. URL: https://suspilne. media/1762-posolstvo-ssa-privitalo-zelenskimkriminalnoi-vidpovidalnosti-za-nezakonne-zbagacenna/.

\section{Анотація}

Юрчишин І. Б. Генезис кримінальної відповідальності за незаконне збагачення в Україні. - Стаття.

Корупція є однією з основних загроз національній безпеці України, а протидія корупції має здійснюватися виключно правовими засобами з дотриманням конституційних принципів та приписів законодавства, ухваленого відповідно до Конституції України.

Стаття підготовленана актуальнутему, оскільки після вжиття законодавцем заходів, спрямованих на відновлення кримінальної відповідальності за незаконне збагачення та доповнення Кримінального кодексу України ст. 368-5, сучасний стан кримінальної відповідальності за незаконне збагачення є малодослідженим.

Автор зазначає, що Україна пройшла унікальний шлях встановлення та трансформації кримінальної відповідальності за незаконне збагачення, а з моменту запровадження кримінальної відповідальності за незаконне збагачення і до сьогодні кримінально-правованорма «незаконнезбагачення» зазнавалазміншість разів, була декриміналізована та згодом відновлена

У статті криміналізація незаконного збагачення визначається як один із правових інструментів та суво- рий засіб державного примусу в загальному механізмі протидії корупції, який характеризується потужним превентивним та каральним антикорупційним потенціалом і органічно пов'язаний та кореспондується 3 обов'язком держави боротися чи іншим чином протидіяти корупції, а також є одним із фундаментів поточної антикорупційної політики та інституційної реформи у сфері боротьби з корупцією в Україні.

У статті розглянуто соціальну зумовленість та історичні передумови встановлення кримінальної відповідальності за незаконне збагачення, здійснено умовний поділ історії становлення кримінальної відповідальності за незаконне збагачення на п'ять етапів її розвитку та надано їм характеристику. На кожному з вказаних етапів надана детальна характеристика кримінально-правовій нормі «незаконне збагачення» .

Автором зроблено обгрунтований висновок, що законодавець перебуває в пошуку найоптимальнішої моделі вказаної кримінально-правової норми, яка б, з одного боку, була ефективним правовим інструментом боротьби з корупцією, а з іншого - враховувала конституційні положення, якими встановлено принципи юридичної відповідальності, права і свободи людини i громадянина, а також їх гарантії.

Ключові слова: корупція, боротьба з корупцією, незаконне збагачення, криміналізація незаконного збагачення, кримінальна відповідальність за незаконне збагачення.

\section{Summary}

Yurchyshyn I. B. The genesis of criminal responsibility for illicit enrichment in Ukraine. - Article.

Corruption is one of the major threats to the national security of Ukraine and fighting against corruption should be realized only by legal instruments which accepted with the constitutional principles and provisions of legislation adopted in accordance with correspondence to Constitution of Ukraine.

The article analyzes the importance of newly implemented measures, directed to restore the criminal liability for illicit enrichment by adding the title 368-5 to the Criminal Code of Ukraine. The current title of criminal liability for illicit enrichment is poorly researched and needs further analysis.

Criminalization of Illicit Enrichment is defined as one of the legal instruments or mechanism, used as a strict measure by the government in order to counteract corruption. Criminalization of illicit enrichment is characterized by powerful preventive and punitive anti-corruption potential. Also, criminalization of illicit enrichment is the government's duty and obligation to combat corruption. This measure is one of the foundations of the current anti-corruption policy and institutional reform of anti-corruption legislation in Ukraine.

The article explains social conditionality and historical prerequisites for establishing criminal liability for illicit enrichment. It also explains the development of the five stages of conditional division of criminal liability for illicit enrichment and defines the characteristics of each stage. At each of these stages, a detailed description of the criminal law title of "illegal enrichment" is provided.

The author concluded the legislator is currently searching for an optimal model that could become a valid legal instrument to tackle the corruption, would follow constitutional provisions, as well as set the principles of legal responsibility, law and freedom, human and citizen, as well as their guarantees.

Key words: corruption, combat corruption, illicit enrichment, criminalization of illicit enrichment, criminal liability for illicit enrichment. 